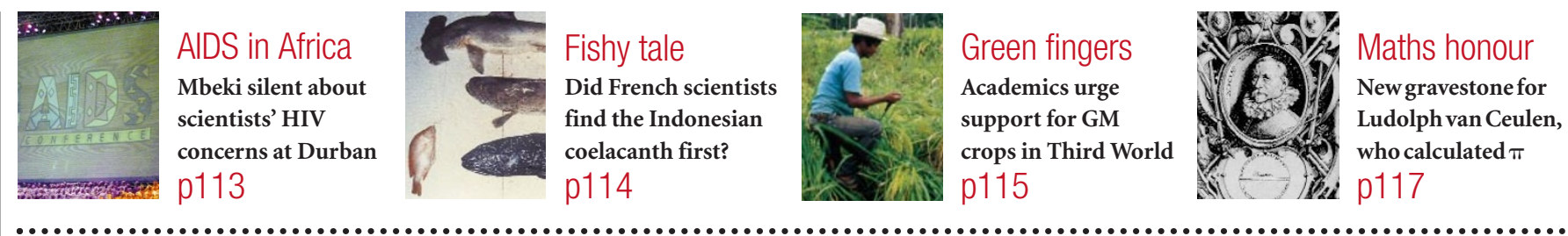

\title{
German agencies sound alarm on risks of broad gene patents...
}

\section{Quirin Schiermeier, Munich}

The heads of two key German science organizations have warned that the award of broad patents on gene sequences could stifle basic genomics research and competition for pharmaceutical innovations.

They are urging Wolf-Michael Catenhusen, the science ministry's secretary of state for research, to explore ways of requiring national and European patent rules to be interpreted in a way that forbids patents covering all possible applications of a particular gene sequence. Instead, patents should be restricted to identified functions.

The warning has come from Detlev Ganten, head of the Max Delbrück Centre for Molecular Medicine in Berlin and president of the Helmholtz Association of National Research Centres, and Ernst-Ludwig Winnacker, president of the Deutsche Forschungsgemeinschaft, Germany's main research funding agency.

Speaking at a press conference last week following the announcement of Germany's new genome research strategy (see Nature $406,6 ; 2000)$, they argued that it should no longer be possible to obtain patent protection on all potential functions of a biological material — such as a gene - and that patents should be restricted to specific functions.

According to the European Patent Convention, product patents on the commercial use of substances such as chemical compounds or biological material - including DNA - may be granted only if the inventor can identify a specific function.

But Winnacker and Ganten criticize the fact that European gene patents can cover all of the potential functions of a DNA sequence. As a consequence, they say, the owner of a patent on a gene sequence could block the commercialization of any newly discovered function of this sequence, or demand a licence fee.

Winnacker referred to the patent held by the American company Human Genome Sciences on the chemokine receptor CCR5, whose role as a 'revolving door' for the HIV virus was completely unknown when CCR5 was first described as a cell receptor for lymphocytes (see Nature 404, 322; 2000). Such

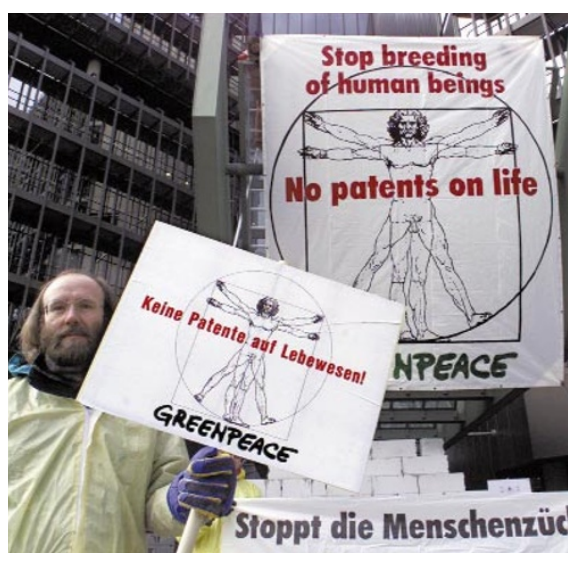

Protective action: Greenpeace is not alone in its protests over the effects of gene patents.

broadly worded patents could deter scientists from researching genes which, for example, overlap with DNA sequences already protected by a patent.

The issue will be discussed over the coming months by patent experts from the federal ministries of science, health and legal affairs as they prepare to adopt as national law the European Union's (EU's) directive on the legal protection of biotechnological inventions, passed in 1998.

The directive will harmonize biotechnology patents in the EU. In principle, patent officers determine whether the breadth of a patent claim is too broad, using the conventional criteria for judging patent applications. But national governments can still require an interpretation of European-level rules that reflects experience of new and rapidly growing areas such as biotechnology.

Jens Reich, a bioinformaticist at the Max Delbrück Centre, says he would welcome any move to limit the scope of patents on gene sequences. He says that a growing number of "equally vague and broad" claims slipping through the patent offices' examination formalities could block real innovation in genomics. "In an ideal world," says Reich, "a patent-relevant description of a gene function should require a careful cell-biological examination of the physiological effects."

But the German pharmaceutical industry wants to see the EU directive adopted as it stands, and does not want specific restrictions added to biotechnology patents. Dieter Laudien, head of the patent committee of the association of research-based pharmaceutical companies in Germany, says that a special treatment of biotechnology patents would violate the international agreement on trade-related aspects of intellectual property rights (TRIPs), which says that there must be no substantial differences between patent rules in different technical fields.

\section{... as spending goes up for research}

Molecular medicine and biotechnology are the big winners in Germany's proposed federal science budget for 2001. As long as it is approved by parliament, total federal spending on science will rise next year by $5.3 \%$, to DM15.37 billion (US\$7.5 billion).

The increase means that the coalition government of Social Democrats and Greens remains loyal to its 1998 election promise to significantly increase spending on research. Within this total, money available for university building and large equipment hitherto notoriously underfunded items - is to increase by DM215 million, and will next year total DM2.22 billion.

The new budget also illustrates Germany's efforts to become a world leader in genomics research (see also Nature 406, 6; 2000). Since 1998, project money available for biotechnology and molecular medicine has risen by $30.4 \%$ and $47.8 \%$, respectively, now reaching DM220 and DM96 million.
Institutional funding of the main research organizations will also rise. The Deutsche Forschungsgemeinschaft, the main funding agency for university research, will get DM1.23 billion, $5 \%$ more than last year. The Max Planck Society, Germany's largest non-university basic research organization, will receive a more modest increase of $3.9 \%$, taking its funding to DM888 million. Both organizations will received similar sums from Länder (state) budgets. 